\title{
Thomas Hobbes and the Political Economy of Peace
}

\author{
PATRICIA SPRINGBORG
}

Humboldt University of Berlin

\begin{abstract}
Summary
Thomas Hobbes's theory of war is currently being re-examined as part of a re-examination of realism in international relations theory which claims to be Hobbes-based. I am not alone in maintaining that Hobbes was first and foremost a peace theorist, rejecting the usual grounds for war, pretexts based on just war, infringements on property or trade, and thus trespass. But those who examine the three-fold causes of war that Hobbes gives, as "competition", "diffidence", and "glory", have generally not noticed the relation between Hobbes's theory of war and empire. While Hobbes makes remarkably few references to the colonial ventures of Great Britain, for reasons that we will consider, his theory of empire, like his theory of war, is based on classical notions of internal balance and the homeostasis of the body politic along Aristotelian lines. His treatment of the polity as a natural body is consistent with his materialist ontology and he treats war and empire in terms of both "intestine diseases" and pathologies that afflict the body politic from without. The upshot is a theory remarkably backward-looking in terms of its emphasis on the health of the body politic and the politics of balance, which forbid "vain-glorious wars" and demand that overly-powerful subjects, towns of "immoderate greatness" and grandiose enlargements of dominion be excised, like Aristotle's "big foot" whose disproportion spoils the proportion of the body as a whole.
\end{abstract}

Keywords: Hobbes, War and Peace, Empire, International Relations, Realism, Bobbitt

\section{Hobbes and the Realists on War and Peace}

Realism in international relations theory takes from Hobbes its basic postulate that order obtains within states as a product of some version of the Social Contract, but that between states the international system, without a sovereign or the possibility of world government, is necessarily in a state of anarchy. ${ }^{1}$ The further realist pos-

1 For standard works on realism, see the early classic, Morgenthau, 1992; Waltz, 2000; Mearsheimer, 2004; Nye, 2004. 
tulate, that anarchy entails competition, conflict and disincentives for cooperation, to the point where the international system, like the state of nature before the social contract, is prone to perpetual war, is also Hobbesian. But what above all differentiates Hobbes from the realists is that Hobbes is a theorist of peace rather than war. ${ }^{2}$ They are further differentiated by the considerable slippage in the realist position between facts and values. What in the case of Hobbes is presented as a set of analytic propositions that constitutes a thought experiment about the origins of government becomes in the case of realist international relations theorists a series of postulates for which empirical support is claimed, and from which they derive normative recommendations that generally do not favour peace, but rather war. This was true in the most extreme form of the advocates of the Bush Doctrine, and particularly Philip Bobbitt, instrumental in formulating it, who slipped from the empirical claim that new world orders are created as the outcome of epochal wars, by victors who impose on the vanquished their own norms and institutions, to the normative claim that the right of the victor entails a duty to impose one's values and institutions on the vanquished (Bobbitt, 2002). Of course nothing like this is to be found in Hobbes who, like Grotius before him, exhibited a new behaviouralism in the treatment of war (see Springborg, 2010a). Departing from the "just war" tradition of the much reviled Aristotelians, and surrounded by the religious wars in which the secular state suffered its birth pangs, both sought principles that would minimize war, which they viewed, not like Clausewitz, as "the continuation of politics by other means" but, like Machiavelli, as the failure of politics.

Recent work has shown that the case of the realists to be Hobbist is flawed (Malcolm, 2002: 440-448). But rarely do critics focus on the simple and overriding fact that the dissimilarity between the realists in international relations theory and Hobbes arises from their most basic postulates. Realists assume the Hobbesian state of nature to represent the original state of humankind, rather than an analytic reconstruction of the conditions for state-creation, and for this reason they see the state of nature to be constituted by bellicose primitives, interest-seekers on whom no moral constraints are operative because none is yet instated. Hobbes's famed characterization of life in the state of nature as "nasty, brutish, and short" (Lev., xiii, §9, 61/76), in its full elaboration in Leviathan would seem to lend support to such a view, but not on a close reading. Were it the case that human beings were congenitally bellicose, Hobbes's project would be a lost cause. Hobbes's account of war is behavioural because it is descriptive rather than normative, but what it describes is an exceptional and not a normal state. Nor is it intended to describe the primitive condition

2 See Delphine Thivet's excellent “Thomas Hobbes: a Philosopher of War or Peace?" (2008), to which I am greatly indebted. See also Bernard Gert's Hobbes: Prince of Peace (2010), reviewed by Michael Funk Deckard (2011). 
of human kind, although Rousseau, who was certainly influential in the reception of Hobbes, read him this way. War is a Behemoth, like the "allegorical monster, dozing for a tract of time, but without being dead for all that, preventing the angel of peace from being revived". ${ }^{3}$ Hobbes, maintaining that "during the time men live without a common power to keep them all in awe, they are in that condition which is called war, and such a war as is of every man against every man" (ibid.: $\S 8,61 / 76$ ), nevertheless followed Grotius in insisting that war is a "status", a condition with well-defined parameters, "a state which may exist even while its operations are not continued". ${ }^{4}$ War as a status is also an exceptional state, having a tempus or a time dimension, but a bounded time. Foreswearing Aristotle's famous analogy that "one swallow", any more than one fine day, "does not make a summer", ${ }^{5}$ Hobbes introduced a parallel analogy that captured the core of his argument:

For WAR consisteth not in battle only, or the act of fighting, but in a tract of time wherein the will to contend by battle is sufficiently known. And therefore, the notion of time is to be considered in the nature of war, as it is in the nature of weather. For as the nature of foul weather lieth not in a shower or two of rain, but in an inclination thereto of many days together, so the nature of war consisteth not in actual fighting, but in the known disposition thereto during all the time there is no assurance to the contrary. All other time is PEACE. (ibid.)

Although embedded in a rights doctrine, Hobbes's concept of war is not strictly juridical, any more than that of Grotius; but nor does he subscribe to the "just war" tradition, to which Grotius subscribed in a qualified way. By focusing on a "disposition to war" as the defining characteristic of the "state of war", he shifts the analysis to human psychological predispositions to war that are the very opposite of those that characterize the normal condition of peace. Hobbes sees these psychological predispositions as, first, "the will to contend" induced by fear of death and the will to self-preservation given the perceived anthropological facts about competition - life-preserving and death instincts that are in constant competition. Second, and not unrelated, is the disposition to "diffidence", or mistrust. And third, "glory", or the desire for self-esteem. What is new about this account is less its psychological and anthropological substance - also to be found in the anthropologies of the ancients, Plato, Aristotle, Stoics, Sceptics and Epicureans - but more the way that Hobbes systematizes it in accordance with the materialist principles of the New Science of his day, and specifically William Harvey's theory of the circulation of the

${ }^{3}$ Haggenmacher, 1983: 459-460, Thivet's translation, 2008: 703.

${ }^{4}$ Grotius, De Jure Belli ac Pacis, bk 3, ch. 21, §1, 592, Thivet's translation, 2008: 702.

5 "One swallow does not make a summer, nor does one day; and so too one day, or a short time, does not make a man blessed and happy." Aristotle, Nicomachean Ethics, I.1098a18. 
blood. ${ }^{6}$ For how these psychological predispositions played out in war Hobbes was also deeply indebted to Thucydides, whom he had translated, and whose "semiotics of war" (Thivet's term) comprised a "world-turned-upside-down" such that even words changed meaning, charged with the hostility of each man toward "the other". ${ }^{7}$ In such a time "where every man is enemy to every man", there is no society and no security to furnish its benefits:

there is no place for industry, because the fruit thereof is uncertain, and consequently, no culture of the earth, no navigation, nor use of the commodities that may be imported by sea, no commodious building, no instruments of moving and removing such things as require much force, no knowledge of the face of the earth, no account of time, no arts, no letters, no society, and which is worst of all, continual fear and danger of violent death, and the life of man, solitary, poor, nasty, brutish and short. (ibid.: $§ 9,62 / 76$ )

No one has outclassed Rousseau's percipient reading of Hobbes on the wellsprings of war. But both philosophers, few have observed, owe their basic narrative of the role of war in the growth of civilization to the ancients, particularly the Stoics and Epicureans, notably the Roman Stoic Seneca's Ninetieth Letter on Progress and the Roman Epicurean Lucretius' De rerum natura book five. ${ }^{8}$ Stoic accounts of the consequences of the passage from the state of nature to civilization in terms of the increasing interdependence of society, and the consequent exacerbation of ten-

${ }^{6}$ Harvey's De Motu Cordis (On the Motion of the Heart and Blood) was published in Frankfurt in 1628, designed for rapid circulation at the Frankfurt book fair.

7 See Thucydides, 1989: I, ii-viii, and especially iii, $\S 82$ : “[ t $]$ he received value of names imposed for signification of things was changed into arbitrary. For inconsiderate boldness was counted true-hearted manliness; provident deliberation, a handsome fear; modesty, the cloak of cowardice; to be wise in everything, to be lazy in everything." Hobbes's translation of Thucydides (1989) bk $3, \S 82,204-205$. In the opening lines of the Historia Ecclesiastica, Hobbes paraphrased the same passage from Thucydides on the power of war to corrupt discourse, manners and morals:

Don't you see that the whole order of things is being altered? That what was once a crime, they now call upright?

Don't you see that treachery, slaughter, perjury, theft and pillage are called the acts of a good citizen?

See Hobbes's Historia Ecclesiastica (2008), lines 9-12, 304-305 and notes (citations to the Historia Ecclesiastica which follow are to this edition).

${ }^{8}$ For an elaboration of this thesis, see Springborg, 1981, chapters 2 and 3, and Cole, 1967; based on the German tradition of Kulturgeschichte, the term used by Cole and a long line of German classicists to characterize the account of the origins of civilization by Stoics, Sceptics and Epicureans, who postulated the interlocking developments of needs-driven technology and constantly expanding mental horizons involved in satisfying them. See also Uxkull-Gyllenband, 1924; Jelenko, 1936; and Walter von Spoerri's important works, “Über die Quellen des Kulturentstehung des Tzetzes" (1957) and Späthellenistische Berichte über Welt, Kultur und Götter (1959). 
dencies to competition to the point where an intensification of the status and honour stakes leads to war, are faithfully replicated by both philosophers, by Rousseau in the Second Discourse, On the Origins of Inequality, and by Hobbes, whom Rousseau had so carefully read, in all his works and especially in Leviathan. Hobbes, nevertheless, made a special contribution to the classical Epicurean theory of war as the product of the interdependency of society accompanying economic and social development, and the intensification of competition once the satisfaction of basic needs allowed the growth of symbolic needs, simultaneous with the development of resources to satisfy them. And that was to systematize the way in which the three psychological well-springs of war give rise to three categorically different kinds of war: first, the "war of necessity" based on the human propensity to compete for goods perceived as scarce; second, preventive war based on "diffidence" or mistrust; and third, offensive war based on "vain glory" and perceived threats to or transgressions against the majestas of a hegemon. All three psychological well-springs of war are susceptible to manipulation by players who stand to gain from the hostilities and, therefore, in Hobbes's view, there are severe limitations on wars, ranked in terms of decreasing legitimacy, that may be rightly waged under their aegis. In the case of the first type, "war of necessity", the uneven geographical distribution of natural resources necessary for survival prompts both a pacific and an aggressive solution: by means of trade, in the first place; or, failing that, by means of conquest and war. Hobbes subscribed to the theory of "goods naturally to be enjoyed in common", endorsed over centuries by the Church Fathers, and more recently debated by the late Scholastics in the context of conquest of the New World: "that such things as cannot be divided be enjoyed in common, if it can be; and if the quantity of the thing permit, without stint; otherwise proportionably to the number of them that have right" (Lev., $\mathrm{xv}, \S 25,78 / 97)$. Where enjoyment in common was not feasible, and enclosure of the land and private property were necessary, Hobbes insisted that conquest and colonization must not allow the dispossession or extermination of the local inhabitants:

The multitude of poor (and yet strong) people still increasing, they are to be transplanted into countries not sufficiently inhabited, where, nevertheless, they are not to exterminate those they find there but constrain them to inhabit closer together, and not range a great deal of ground to snatch what they find, but to court each little plot with art and labour, to give them their sustenance in due season. (Lev., $\mathrm{xxx}, \S 19,181 / 228-229)$

Only "when all the world is overcharged with inhabitants, then the last remedy of all is war, which provideth for every man, by victory or death" (ibid.: 181/229). Like his mentor Francis Bacon before him, Hobbes advocated free trade as a solution to the problem of scarcity superior to war, while also acknowledging that trade relations, as systems of preferential treatment, can themselves be the cause of war: 
It is also a law of nature, that men allow commerce and traffic indifferently to one another. For he that alloweth that to one man, which he denieth to another, declareth his hatred to him, to whom he denieth; and to declare hatred is war. And upon this title was grounded the Great War between the Athenians and the Peloponnesians. For would the Athenians have condescended to suffer the Megareans, their neighbours, to traffic in their ports and markets, that war had not begun. (Hobbes, The Elements of Law, xvi, §12)

In the case of the second type of war, "preventive war", resulting from "diffidence" (metus), or fear, Hobbes is consistent in distinguishing between objective and subjective assessments of insecurity, the latter subject to manipulation by those who stood to profit from the escalation of hostility by a growth in imperium. Although acknowledging that humans are so constituted that mistrust or diffidence provokes "anticipation, that is by force, or wiles, to master the persons of all men he can, so long, till he see no other power great enough to endanger him", it is the escalation of unbounded fear by manipulation to which Hobbes insists on setting strict limits:

For not every fear justifies the action it produceth, but the fear only of corporeal hurt, which we call bodily fear, and from which a man cannot see how to be delivered, but by the action. [...] But to kill a man, because from his actions, or his threatenings, I may argue he will kill me when he can, (seeing I have time and means to demand protection from the sovereign power) is a crime. (Lev., xxvii, $\S 20,155 / 196)$

If self-defence does not mitigate the crime of murder in individual cases, nor does it in the case of mass killing, or war. Hobbes does allow self-defence in the restricted case of bodily or physical threat, as belonging to "the right of nature", that is to say the law-exempt behaviour of the state of nature, characterized by the "right to all things". For "As long as a person has no guarantee of security from attack, his primeval Right remains in force to look out for himself in whatever ways he will and can, i.e. a Right to all things, or a Right of war" (Hobbes, De Cive, II, $\mathrm{Ch} . \mathrm{V}, \S 1,69$ ). But once the law of nature (lex naturalis) has been admitted with the social contract, and erected by the sovereign in the form of positive law (lex), one's defence, in all but individual cases of physical threat to one's person, falls to the sovereign. ${ }^{9}$ Nor does Hobbes allow sovereigns unlimited war powers. He makes no room, as Thivet points out, "for war as punishment for the violation of rights or injury received, as theorized for instance in Grotius's De Jure Belli ac Pacis"

9 Lev., xiv, §1-2, 64/79. I owe this insight to Michael Funk Deckard's unpublished paper, "Hobbes on Peace: Anthropology and the Politics of the Sovereign", 6, citing ibid.: §3, 64/79: "The 'right' to defend oneself 'consisteth in liberty to do, or to forbeare,' but the 'law, determineth, and bindeth to one of them: so that Law, and Right, differ as much, as Obligation, and Liberty; which in one and the same matter are inconsistent"”. 
(Grotius, De Jure Belli ac Pacis, II, Ch. I, §2, 102; see Thivet, 2008: 713); and nor, therefore, is he interested in the merits of the case for defensive war against an aggressor. War is typically waged on the pretext of self-defence and subsequently legitimated by the peace treaty that concludes it; and has its analogue in the case of conquest, also legitimized de facto. This is simply a behavioural fact about human beings, but defensive wars, for all that, are not legitimate. Hobbes fills out the behavioural account of how states prepare their defences, establishing "the obedience and unity of the subjects", raising "the means of levying soldiers", "having money, arms, ships, and fortified places" (Hobbes, The Elements of Law, II, Ch. IX, §9); all the time insisting that the best defence lies "in the avoiding of unnecessary wars". ${ }^{10}$ Like Machiavelli he believes that armaments are not the answer, the Prince should build fortresses in people's hearts (Machiavelli, Il Principe, Ch. XX, §6).

Hobbes pays greatest attention to the irrational inflation of fear by those who stand to gain from it as the source of mass hostilities, and this holds in all three types of war. Fear, indeed, is the source of all institutional power to the extent that, on the basis of the social contract by which individuals trade obedience for protection, institutions claim to offer them solace for their existential fears. Hobbes's extended treatment of religion as rooted in fear, and the purchase that it gave to priests; his condemnation of the doctrine of "twin spheres", that allowed the division of "spiritual" and "temporal" kingdoms, the kingdom of God and the kingdom of man, each at war with one another; and his account of the rise of the papacy as an imperial edifice built on the exploitation of fear, all represent ramifications of this thesis. All those who owe their power to the manipulation of fear stand equally condemned for their "frauds and wicked skills" in preying off the defenceless. ${ }^{11}$ Thus: "Force and fraud are in war the two cardinal virtues" (Lev., xiii, §13, 63/78).

Defensive war morphs into offensive war, and the third cause of war, "vain", from "vain glory" as the well-spring of offensive war, is for Hobbes the least legitimate and the most severely condemned: "Of the passions that most frequently are the causes of crime, one, is vain glory, or a foolish overrating of their own worth" (Lev., xxvii, §13, 154/194). "Vain" wars, waged, "for [such] trifles, as a word, a smile, a different opinion, and any other sign of undervalue, either direct in their

${ }^{10}$ Cited by Thivet, 2008: 713. And here I agree with Funk's criticism of Thivet, that she conflates self-defence as the means to self-preservation as a "right of nature", with defensive wars in response to aggression, concluding that as "necessary wars" to secure basic needs they are "just wars". In fact Hobbes does not see even wars of self-defence as "just", because states tend to overstate their security needs and good policy means the avoidance of war.

11 Hobbes, 2008: 314-315, lines 109-110. The epigram is from Ovid's Metamorphoses I.130-1, characterizing the Iron Age, a period of brutal war, and appears on the title page of the 1688 printed edition of Hobbes's poem, probably selected by the editor, Thomas Rymer, who also provided the excellent Preface. 
persons, or by reflection in their kindred, their friends, their nation, their profession, or their name", are indeed in vain (Lev., xiii, \$7, 61/76). They characterize self-devouring status-bound societies in which the pursuit of honour begins where basic needs end, status having an unlimited capacity to feed off itself, a topos familiar from the Roman Epicurean Lucretius in his De rerum natura book 5, which Rousseau greatly developed in his Essay on the Origins of Inequality. The overinflation of ego, redescribed by Rousseau as "amour propre", negative ego-centric love, as opposed to the positive self-regarding "amour-de-soi", is a perennial source of social conflict. ${ }^{12}$ This type of psychic distortion characterizes aristocratic and "dueling" societies. It belongs to a more systematic exploration by Hobbes of the way in which human frailties like vanity and fear become pressure points for institutional manipulation and sources of social conflict that are in fact absent in the state of nature, where the struggle is about basic needs, rather characterising society after the social contract, and magnified in more refined societies enjoying the closet politics of early modern courts. ${ }^{13}$

Here, too, Hobbes elaborates in a psychologically compelling way a thesis that is present only in germ in the Ancients. We find it first in Plato's Republic, and his account in Book 1 of the development from subsistence society to a society that can support the good life, and more fully elaborated in his account of the reconstruction of society after the Flood, in the Laws. We find it also in the Stoics and Epicureans, for instance in the Stoic Seneca's Ninetieth Letter on Progress and the Roman Epicurean Lucretius' De rerum natura, to be picked up and further elaborated by Rousseau. Hobbes, like Rousseau, the Jansenists, and later Freud, was a Manichaean, postulating in humans both life-preserving instincts and death instincts and a constant drive to resolve them in the pursuit of peace. He therefore could not concur with international relations realists that the international system is in a state of anarchy based on an overriding human predisposition to war. Most likely he would condemn them, like the priests, for inducing a permanent state of fear in which humans then overshoot in their efforts to provide the security, that by overreaching, they only succeed in putting forever out of reach. Once again this is an ancient and characteristically Epicurean topos, but developed by Hobbes to provide a systemic account of the power of social institutions. If fear of death and the void, and its inflation by priests, is the power source of institutionalized religion, then glory, and its inflation in hierarchical societies devoted to conspicuous display, is the source of the most irrational and self-perpetuating jealous struggles. In war both may intersect, and particularly in civil war, the most destructive form of mass conflict, and in

12 For a development of this thesis, see Springborg, 1981, chapter 3, "Rousseau on Natural and Artificial Needs".

13 See Sharpe, 1983, 1987; Cuddy, 1987; Adamson, 1999; Shephard, 1992; Wootton, 1999. 
the case of the one he lived through, fomented, he believed, by priests, Presbyterians and "democratical gentlemen" (Hobbes, Behemoth, 39).

\section{Hobbes and the Realists on War and Peace}

Modern international relations theory from its very inception has, for various historical reasons, been dominated by Thomas Hobbes, but a vulgarized Hobbes, as Noel Malcolm, Delphine Thivet and Bernard Gert have established. Noel Malcolm examines the provenance of the stereotypical view of Hobbes as a realist in international relations theory, which he locates in Hobbes's "utter rejection of teleological metaphysics, and his strict derivation of the natural laws from the principle of individual self-preservation [which] set him far apart from the mainstream of rationalist natural law theories" (Malcolm, 2002: 455) ${ }^{14}$ Malcolm concludes that "unlike the Stoic, scholastic, or Lockean versions of natural law, Hobbes's theory takes no cognizance of the good of mankind as such" (ibid.). Most importantly, Malcolm notes that " $[t]$ here can therefore be no equivalent in it [Hobbes's theory] to Locke's concept of the 'executive power of the law of nature', by virtue of which a third party can intervene in other people's affairs to enforce that which is objectively right" (ibid.). It is this latter feature of Hobbes's theory, which prohibits interventionism, and which distinguishes it from that of Locke, on which I now wish to focus.

The dominant realist paradigm of a system of states, internally ordered but in a state of anarchy among themselves, is heavily tilted towards materialism, but in a non-Hobbesian way. The problem of order in the international system, according to the realist model, is solved in terms of a Social Darwinian survival of the fittest, determined in terms of brute capacity: the strongest wins, and strength is measured in terms of military and economic might. In this way a more or less incidental, but nevertheless disturbing feature of Hobbes's and Locke's state of nature theory, that the struggle of all against all, like the battle between the sexes, is won by the stronger, is elevated into a dominant principle. (Both Hobbes and Locke discourse at length on the fact that men and women are in principle equal, but that because convention has it that women are the weaker sex, men win, and then apply the model to the state of nature by allowing brute capacity to determine the outcome. ${ }^{15}$ )

14 See "Hobbbes's Theory of International Relations" (Malcolm, 2002: 432-456).

15 Both Hobbes and Locke maintained that men and women are free and equal in the state of nature and in civil society, and that whatever advantage accrues to the male due to brute strength must not translate into domination over his wife. See Hobbes, Lev., xix, §72, 100/126, and Locke, The Second Treatise on Government, ch. 7, §82: "The last determination... naturally falls to the man's share, as the abler and the stronger. But this reaching but to the things of their common interest and property, leaves the wife in the full and free possession of what by contract is her peculiar right, and gives the husband no more power over her life than she has over his." 
The difference is that for both Hobbes and Locke the resolution of the problem of anarchy in the state of nature is a thought experiment based on an appeal to rights and reason, and not an exercise in brute capacity. The genius of the social contract as a solution to the problem of anarchy that the state of nature poses, and the strongly rhetorical elements involved in the Hobbes-Locke model, simply drop out of the realist paradigm and are only now being reinserted by the neo-realists and constructivists in the form of "Soft Power" (see Nye, 2004).

None of this would be of more than academic interest, perhaps, were it not for the fact that the realist model of international relations theory and its preoccupation with brute capacity has been so dominant in foreign policy, and in many cases, disastrously so. This applies not only in the case of post-WWII Anglophone foreign policy, but also to the work of Carl Schmitt, juridical architect of the Third Reich and author of the frighteningly brilliant modern Leviathan. ${ }^{16}$ If the Anglophone world contributed to neo-Hobbesian realism a strong current of social Darwinism, the Germanic world contributed the theory of von Clausewitz and his famous adage that "War is the continuation of politics by other means". The upshot was a vulgarized Hobbes that is in a sense self-defeating. If, as Thrasymachus put the case so early in Plato's Republic, politics is governed by might over right, or as Hobbes was later to observe, "Clubs are Trumps" (Of Punishments, in Hobbes, 1971: 140), then all of the subtleties of social contract and theorizing about Justice and how to operationalize it since Plato are in vain. This vulgarized Hobbes who worships the idol of brute capacity seems to dominate modern international relations theory, frequently involving a slippage from fact to value, from empirical observation to recommendation.

One instance of this slippage is Philip Bobbitt's move in The Shield of Achilles (2002) from the observation that victors of epochal wars do in fact establish as hegemonic their own goals and values, to the claim that they have the right to do so - a claim perhaps derived from Locke's notion of "the executive power of the law of nature", which allows, if it does not indeed enjoin on the hegemon, the right of intervention in the affairs of sovereign nations to enforce "that which is objectively right". ${ }^{17}$ To this heady mix of high-minded Lockean natural law theory and Machi-

16 Schmitt, 1938/1995, translated as Schmitt, 1996, by George Schwab. On Hobbes and Schmitt, see Bredekamp, 1999 and Bredekamp's book, Thomas Hobbes visuelle Strategien (2006). See also Springborg, 2010b republished in Tralau, 2011.

17 Locke, The Second Treatise on Government, ch. 2, §7:

And that all men may be restrained from invading others rights, and from doing hurt to one another, and the law of nature be observed, which willeth the peace and preservation of all mankind, the execution of the law of nature is, in that state, put into every man's hands, whereby every one has a right to punish the transgressors of that law to such a degree, as may 
avellian Realpolitik, Bobbitt adds a preoccupation with brute capacity and materialist measures of power that are the hallmark of realist international relations theory. So for instance he concludes from the Hobbesian thesis that sovereignty obtains only within states and that the system without is in a state of anarchy, the Schmittian thesis that war is the natural condition of the state. He makes a number of supporting claims on the relation between war, the state and strategy based on his primary thesis that states exist to make war. ${ }^{18}$ Niccolò Machiavelli is famous as among the first to advance the thesis that all states are founded in violence. But to conclude from this that war is the natural condition of states is to commit the genetic fallacy, or the argument from origins that slips from an empirical fact about the origin of states to the claim that in the nature of things it should be so, from is to ought. Bobbitt then goes on to convert Max Weber's empirical observation that the origin of modern states lay in the administrative structures necessary to fund larger armies, from a descriptive to a prescriptive thesis (Bobbitt, 2002: xxii, 70). Such slippage we never find in Machiavelli, much less Hobbes. Both Machiavelli and Hobbes wrote to advance peace, a futile mission were war the natural condition of states.

The corollary of the doomsday thesis that war is the natural condition of states is that it falls to the hegemon to manage aggression, and on this conclusion Bobbitt advances a number of theses of striking relevance. He observes, with apparent approval, that Germany and Russia resolved constitutional issues by violence (ibid.: 25-27) - in Bismarck's case in order to defeat parliamentarianism, self-government and the threat of Revolution. He adopts the Dr. Strangelove position of praising the successful Allied strategy of "going to war to stop aggression" (ibid.: 9), and sees the string of regional wars in which America has been involved since WWII as exercises in this strategy. Further, he admires Bernard Brodie and the genius of nuclear deterrence in producing "a balance of terror" (ibid.: 12) as an important elaboration

hinder its violation: for the law of nature would, as all other laws that concern men in this world 'be in vain, if there were no body that in the state of nature had a power to execute that law, and thereby preserve the innocent and restrain offenders. And if any one in the state of nature may punish another for any evil he has done, every one may do so: for in that state of perfect equality, where naturally there is no superiority or jurisdiction of one over another, what any may do in prosecution of that law, every one must needs have a right to do.

18 A sample of these assertions includes the following: the state exists to master violence (Bobbitt, 2002: 216); the characteristic of the nation state is total war (ibid.); constitutional security is secured by violence (ibid.: 16-17); legitimacy must "cloak the violence of the state" (ibid.: 17); states are legitimated by war (ibid.: xxii); a state without a strategy for war cannot maintain its legitimacy (ibid.: 815); the attachment of parliamentary governments to law rather than violence is fatal (ibid.: 28); parliamentary regimes weaken their own legitimacy by failing to act abroad (ibid.: 8); Liberal Constitutional regimes can only survive by revolutionizing their militaries (ibid.: 812). 
of that strategy, going on to enumerate the conditions under which the US will compel others by force (ibid.: 14) - as the right of victor in "the Long War", that is to say the epochal war, as he terms it, that stretched from 1914 to 1989 and established American hegemony.

Paradoxically, Hobbes anticipated what is now referred to as the "security dilemma", or "spiral model", terms used in international relations theory for the dilemma that ensues from the fact that the defenses states put in place to increase their own security, by causing other states to act similarly, thereby actually decrease their security. ${ }^{19}$ Realist international relations theorists are prepared to recognize the dilemma, but generally without acknowledging that it is a product of the reflexivity of their own assumptions. What is axiomatic in realist theory, that the international system is necessarily a state of anarchy, becomes a self-fulfilling prophecy. Moreover, instead of seeing the "security dilemma" as the product of contradictions internal to the theory, realists present it as a set of empirical facts, from which normative recommendations are then derived. Nor are the normative recommendations usually in terms of the dismantling of the arms race, but rather typically urge its intensification in the hopes of gaining an advantage, either in the form of "first strike", or technological superiority. So the implications of the dilemma are not seen to be its own falsification. Even neo-realists and constructivist international relations theorists do not yet see the "security dilemma" as symptomatic of the circularity of the realist position (Wendt, 1992, 1999).

This circularity is present in Hobbes as well, but it does not damn his theory in the same way. Fear in the Hobbesian state of nature, as in the anarchic world of international relations of the realists, causes people to arm themselves to the teeth, but these very measures to combat fear in fact raise the security stakes, and so a vicious cycle of fear, and security measures leading to greater fear, ensues. So, Hobbes argues:

every man, especially those that are over-provident [overly-prudent] are in the estate like to that of Prometheus. For as Prometheus (which, interpreted, is the prudent man) was bound to the hill of Caucasus (a place of large prospect where an eagle, feeding on his liver, devoured in the day as much as was repaired in the night), so that man which looks too far before him, in the care of his future time, hath his heart all the day long gnawed on by fear of death, poverty or other calamity, and has no repose, nor pause in his anxiety, but in sleep. (Lev., xii, §5, 52/64)

Hobbes takes a further step that the security dilemma theorists do not take, and that is to argue that the climate of fear produces psychic distortion. For, "fear in the

19 The term was coined by John H. Herz in Political Realism and Political Idealism (1951). See also Jervis, 1976, 1978; and Roe, 1999. 
absence of causes" leads humans to overshoot in the explanation of these causes, postulating "invisible powers" that empower others to enslave them. It is this fear, and specifically fear of death, that motivates humans to authorize a sovereign to end the "war of all against all" in the state of nature by erecting government. Fear also empowers religion, its structures and edifices whereby a future world of happiness is hoped to compensate the misery and insecurity in this world. And, in the international system, where anarchy still reigns, it also empowers empire and hegemonic structures that are monuments to vain-glory with all the ideological trappings of religion. Vain-glorious power reached its apogee, in Hobbes's estimation, in the power of the Pope, affecting the title of the High Priest of Imperial Rome, pontifex, and commanding his world like an oriental despot, with a nod and much foot-kissing:

The glory of the Roman Pontiff was once immense, he trampled Royal necks with his feet. ${ }^{20}$

Countless kings used to await his commands and he used to wage wars with the help of these tame kings.

People trembled at his thunderbolts ${ }^{21}$ as if they were Jupiter's, planting fawning kisses on his holy feet. ${ }^{22}$

Every wind blew riches to him, the chill East wind, the African wind, the West wind and the North.

Immovable, he kept everything in balance with a nod that commanded reverence; ${ }^{23}$ he had nothing to bother about except to keep his mouth open. (Hobbes, Historia Ecclesiastica, lines 2186-2194, 573-575)

\section{Hobbes on Colonialism and Imperialism}

If Hobbes, the patron of realism, was not a warrior, he was not an imperialist either. Although carefully attuned to the nexus between imperium and dominium (see Coleman, 1985), Hobbes saw the Americas primarily as "empty lands", into which "the multitude of poor (and yet strong) people still increasing... are to be transplanted"

${ }^{20}$ Legend has it that Pope Alexander III trod upon the neck of Frederick Barbarossa to humiliate him; a story repeated by John Milton in his Tetrachordon: Expositions upon the four chief Places in Scripture which treat of Marriage or Nullities in Marriage (1645).

${ }^{21}$ Also a term for powerful commands - see thunderbolts as the insignia of papal power in the frontispiece to Hobbes's Leviathan.

${ }^{22}$ Audiences with the Pope, for all but sovereign princes, required kissing the cross on his right shoe - see the reference to kissing the Pope's toe, in Hobbes, Historia Ecclesiastica, line 2224.

23 Reference to Jupiter's nod, which ratifies his decision and makes Olympus tremble: Aeneid 9.106 from Iliad 1.528-530. The idea of the Pope balancing the world with a nod may also refer back to Archimedes balancing the globe, Plutarch, Life of Marcellus (1965: 99). 
(Lev., xxx, §19, 181/228), when resources run out at home. Hobbes advanced a proto-Malthusian, proto-"Little-England" policy that put emphasis on work and productivity which, by raising the standard of living, was likely to cause both an increase in population and a shortage of natural resources. It required those "as have strong bodies... be forced to work; and to avoid the excuse of not finding employment, there ought to be such laws as may encourage all manner of arts; as navigation, agriculture, fishing, and all manner of manufacture that requires labour" (ibid.). Like Bacon he operationalized the slogan "knowledge is power" to harness the New Science to the conquest of nature and the provision of a commodious existence, but unlike Bacon he did not glory in imperial conquest. After all, he was writing in the lead up to, and then the wake of, the regicide, not a very optimistic period for British imperialists, unlike his French colleagues, who basked in the glory of their "Sun King". By the time he came to write Leviathan, the short-lived Virginia Company, founded by James I in 1606 as a joint stock corporation to handle the settlement of Virginia, and to which Hobbes belonged as one of the most active members, attending at least 37 meetings, ${ }^{24}$ had already failed, largely as a consequence of the Jamestown Massacre of 1622 where native Americans had exacted cruel revenge on the Virginian colonists for their expropriations. As a consequence the increasing non-profitability of the Virginia Company caused the British government to revoke its charter in 1624, at which point Virginia became a Crown colony. In the very few remarks that Hobbes makes about America, we see the legacy of the Indian massacre perhaps in his pessimistic account of race relations and inaccurate claims about "the savage people in many places of America", whom he claims "have no government at all, and live at this day in that brutish manner" he had already described as the war of all against all of the state of nature, "where there were no common power to fear", warning his readers that this was "the manner of life which men that have formerly lived under a peaceful government use to degenerate into, in a civil war" (Lev., xiii, §11, 62/77).

A generational gap into which the Jamestown Massacre falls, accounts in great part for the much greater presence of America in the work of Locke compared with that of Hobbes, who was nevertheless not lacking in interest in imperial structures, but more preoccupied with those of Spain and the Papacy than the British colonies. Just as a generation forward Locke was an American enthusiast, so a generation back, Francis Bacon, whom Hobbes served as an amanuensis and translator, was also a great enthusiast of empire, having been active in promoting British colonies in Virginia, the Carolinas, and Newfoundland, where James I granted him land. But

${ }^{24}$ See Malcolm, 1981, reprinted in his Aspects of Hobbes (2002: 53-79). For an extended analysis of the impact of the Virginia Company on Hobbes's theory of war, economics and empire, see Springborg, 2015. 
generational differences alone cannot account for Hobbes's attitude to empire. The moderateness that we find in his treatment of war forbids imperial enthusiasm as it forbids all forms of vain-glorying. Like the ancients, Hobbes sees commonwealths as bodies that have bios, whose shape is rise, maturation and decline. Like human bodies they procreate and disport themselves abroad, exposing themselves to all the vicissitudes of over-extension that threaten to hasten their demise. His position once again reflects the conservatism of the ancients, whose fear of premature corruption of the body politic due to imperial overstretch and excess led them to caution against foreign entanglements and, in the case of Plato and Aristotle, even to ban foreign trade and commerce.

There is a parsimonious elegance in the way in which Hobbes conceives the body politic to work, on the age-old analogy of the natural body. If monarchs are their heads, ministers for public and economic administration are their arms (Lev., xxiii, §3-4, 123-124/156), while colonies are their natural children:

The procreation (or children) of a commonwealth are those we call plantations or colonies, which are numbers of men sent out from the commonwealth, under a conductor or governor, to inhabit a foreign country, either formerly void of inhabitants or made void then by war. (Lev., xxiv, §14, 131/164)

Colonies may "remain united to their metropolis, as were the colonies of the people of Rome, and then they are no commonwealths themselves, but provinces and parts of the commonwealth that sent them" (ibid.: 131/164-165). But Hobbes cautions that, like natural children, colonies should normally grow up to become free, independent commonwealths in their own right, "discharged of their subjection to their sovereign that sent them (as hath been done by many commonwealths of ancient time), in which case the commonwealth from which they went was called their metropolis, or mother, and requires no more of them than fathers require of the children whom they emancipate and make free from their domestic government (which is honour and friendship)" (ibid.: 131/164).

In treating the causes of the "Dissolution of a Commonwealth" in chapter xxix, Hobbes faithfully pursues the comparison to natural bodies which, more than an analogy, represents rather the consistent application of his materialism under the rubric that "every part of the universe is body, and that which is not body is no part of the universe". ${ }^{25}$ Bodies may perish from "intestine diseases", as they may perish from intestine (internal) war, "in the first place those that arise from an imperfect institution, and resemble the diseases of a natural body which proceed from defectuous [defective] procreation" (Lev., xxix, §2, 167/210). Again following the ancients

${ }^{25}$ Lev. xlvi, $\S 15,371 / 459$. A rule that also forced him to insist on a Corporeal God, see Springborg, 2012. 
and Machiavelli, Hobbes lists among the "infirmities" of a commonwealth internal constitution, first, and sedition, second (ibid.: §6, 168/212). He extends the ambit of sedition, entirely consistent with the classical doctrine of civil religion, third, to cover doctrines that interpose individual conscience against sovereign command, or use "supernatural inspiration" as a pretext for resistance, and the "supernaturally inspired" as judges of good and evil (ibid.: §8, 169-170/212). Hobbes departs from Aristotle, if not from Plato or Machiavelli, in seeing a fourth cause of the death of kingdoms the rule allowing that "the sovereign power is subject to the civil laws"; but does not depart from the classical authors in the fifth cause, " $[t]$ hat every private man has an absolute propriety in his goods, such as excludeth the right of the sovereign" (ibid.: $\S \S 9,10,170 / 213$ ). But he does depart from the ancients in the sixth cause, the doctrine that "the sovereign power may be divided" (ibid.: §12, 170/213), and this represents his repost to Lord Clarendon whose support of "mixture" or the classical doctrine of the mixed constitution, subscribed to by Polybius and Machiavelli in the Discorsi (although not in Il Principe), caused Hobbes to break with his old friend.

On divided sovereignty as the cause of the continual disturbances and "seditions of the aristocratical and democratical factions" of the Greek city states (ibid.: $\S 13,170 / 214)$, Hobbes follows Machiavelli, who in The Prince saw it as a cause of the corruption of Italia. And it is in this context that Hobbes excoriates those classical Greek and Roman writers who, in recommending divided sovereignty or, worse, popular government, secreted a venom like that of a rabid dog:

he that is bitten... is in such an estate as if the poison endeavoured to convert him into a dog, so when a monarchy is once bitten to the quick by those democratical writers that continually snarl at the estate, it wanteth nothing more than a strong monarch, which nevertheless out of a certain tyrannophobia (or fear of being strongly governed), when they have him, they abhor. (ibid.: §14, 171/215)

"Mixed monarchy", or sovereignty divided between king, lords and commons, Hobbes sees as a fallacy perpetrated in his own day on the model of the Trinity. "In the kingdom of God there may be three persons independent, without breach of the unity of God that reigneth; but where men reign, that be subject to diversity of opinions, it cannot be so"; a kingdom in which king, lords and commons all bear the person of the people, or a part of the people, "are not one person, nor one sovereign, but three persons and three sovereigns" (ibid.: §16, 172/217). In the Historia Ecclesiastica (lines 751-752, 392-393) he is even bolder, claiming that since "the Greek word for substance is 'hypostasis'; one who says there are three hypostases says there are three Gods".

So Hobbes convicts those parliamentarians who make the case for king, lords, and commons as sovereign of the same absurdity as those who support the doc- 
trine of the three persons of God in the Trinity, adding the provocation of his own unorthodox doctrine, which claims that God has as many persons as often as he is personated. And he does it while railing at the "spiritual" doctrines of the Scholastics, as "a disease which not unfitly might be compared to the epilepsy, or falling sickness (which the Jews took to be one kind of possession by spirits) in the body natural", which takes the form of "an unnatural spirit (or wind) in the head that obstructeth the roots of the nerves and, moving them violently taketh away the motion which naturally they should have from the power of the soul in the brain, and thereby causeth violent and irregular motions (which men call convulsions)" (Lev., xxix, $\S 15,172 / 216)$. For "as he that is seized therewith falleth down... so also in the body politic, where the spiritual power moveth the members of a commonwealth (by the terror of punishment and hope of rewards, which are the nerves of it) otherwise than by the civil power (which is the soul of the commonwealth)" (ibid.).

Mixarchy, or "mixed monarchy", "is not government" at all, according to Hobbes, "but division of the commonwealth into three factions", and a pathology caused in the body politic where "there be more than one soul, as when the power of levying money (which is the nutritive faculty) has depended on a general assembly, the power of conduct and command (which is the motive faculty) on one man, and the power of making laws (which is the rational faculty) on the accidental consent, not only of those two, but also of a third" (ibid.: §16, 172/216). Thus, "when... these two powers [church and state] oppose one another, the commonwealth cannot but be in great danger of civil war and dissolution". Mixarchy, and worse, a commonwealth divided between church and state, are the ultimate infirmities caused by a false constitution, which defeat Hobbes in terms of "natural diseases". Rather they are gross deformities, like to the image he confesses to "hav[ing] seen [of] a man that had another man growing out of his side, with an head, arms, breast, and stomach of his own"; in the case of mixarchy, he adds: "if he had had another man growing out of his other side, the comparison might then have been exact" (ibid.: §17, 172/217)!

\section{Hobbes on Money, Commodities, Commerce, Commonwealth and Volatility}

C. B. MacPherson's audacious book, The Political Theory of Possessive Individualism: Hobbes to Locke (1962) has long fallen out of favour. But in truth, without having to concede that Hobbes is the author of a theory of possessive individualism, we can concede that, in the tradition of Aristotle's economics and that of the late Scholastics, he developed a rudimentary theory of capital, commodities, commerce, and financial volatility that foresaw economic development, population expansion, colonial adventurism, the possibility that the tail can wag the dog, and that colonies can undo the imperial mother country because of the dynamics of imperial 
over-extension. It is true that he expresses his arguments in the registers of medieval and Renaissance notions of internal balance and the homeostasis of the body politic favoured by the medical sciences of his day. Having "named such diseases of a commonwealth that are of the greatest and most present danger", and these gross deformities, Hobbes turns from "intestine diseases" to infirmities that are intermediate between those that afflict the body politic from within and those that afflict it from without, like "Want of Money", and specifically, "the difficulty of raising money, especially in the approach of war" (Lev., xxix, §18, 172/217). Money as at once the measure of value and at the same time stored-up commodities - twin features which constitute the vulnerability of coinage to depreciation and volatility - is the life-blood of the commonwealth, and as its circulation is essential to health, so its obstruction can cause the demise of the body politic. Hobbes follows Aristotle in seeing that the "expansion of dominion" is an occupational hazard for commonwealths, due to the fact that money as a measure of value is vulnerable to the vicissitudes of any general measure of exchange, so that a reserve currency can be devalued at home due to financial volatility abroad. ${ }^{26}$ Familiar to us from Marx, Hobbes undoubtedly took his theory of money, like Marx, from Aristotle's Nicomachean Ethics book 5 and late scholastic commentaries. But he builds his argument on the very specific anthropology that he has already set out in human psychological predispositions already discussed, and in terms of the passions. If "glorying" is an excellence that tends to excess in the form of "vain-glorying" - and here he diverges from Aristotle, who praises the grandness of the megalopsuchos (Aristotle, Nichomachean Ethics, 4.3), as Machiavelli also praises magnificence - this frailty in individuals is writ large in states.

Excess and disequilibrium are systemic due also to the facts of economic insufficiency: that commodities are perishable, that their value must therefore be substituted by money, and by resort to trade and commerce to provide need-satisfiers. "The Nourishment of a Commonwealth consisteth in the Commodities of Land and Sea" (Lev., xxiv, §1, 127/159), he declares, and these commodities are "partly $n a$ tive and partly foreign: native, that which is to be had within the territory of the commonwealth, foreign, that which is imported from without" (ibid.). Moreover, "because there is no territory under the dominion of one commonwealth (except it be of very vast extent) that produceth all things needful for the maintenance and motion of the whole body", commonwealths make up the deficit "by importation of that which may be had abroad, either by exchange, or by just war, or by labour; for

${ }^{26}$ Hobbes notes "that coin which is not considerable for the matter, but for the stamp of the place, being unable to endure change of air, hath its effects at home only, where also it is subject to the change of laws, and thereby to have the value diminished, to the prejudice many times of those that have it" (Lev., xxiv, §12, 130/164). 
a man's labour also is a commodity exchangeable for benefit, as well as any other thing" (ibid.: $\S 4,127 / 160$ ). Hobbes observes, perhaps with reference to Britain and certainly with respect to Greece, that some commonwealths with small territories have successfully "increased their power, partly by the labour of trading from one place to another, and partly by selling the manufactures whereof the materials were brought in from other places" (ibid.). But once again overstretch is always a danger because of the exogenous power of money. If "[t]he Nutrition of a commonwealth consisteth in the plenty and distribution of materials conducing to life; in concoction (or preparation); and (when concocted) in the conveyance of it, by convenient conduits, to the public use" (ibid.: §1, 127/159), it follows that "Money [is] the Blood of a commonwealth", because "concoction" means "the reducing of all commodities which are not presently consumed, but reserved for nourishment in time to come, to some thing of equal value, and so portable as not to hinder the motion of men from place to place... And this is nothing else but gold, silver, and money" (ibid.: $§ 11,129 / 163$ ).

For gold and silver, being (as it happens) almost in all countries of the world highly valued, is a commodious measure of the value of all things else between nations; and money (of what matter soever coined by the sovereign of a commonwealth) is a sufficient measure of the value of all things else, between the subjects of that commonwealth. By the means of which measures all commodities, moveable and immoveable, are made to accompany a man to all places of his resort, within and without the place of his ordinary residence; and the same passeth from man to man within the commonwealth, and goes round about, nourishing (as it passeth) every part thereof, in so much as this concoction is, as it were, the sanguification of the commonwealth; for natural blood is in like manner made of the fruits of the earth, and circulating, nourisheth by the way every member of the body of man. (ibid.: 130/163-164)

Gold and silver are monarchs in their own right, they "have the privilege to make commonwealths move, and stretch out their arms, when need it is, into foreign countries, and supply not only private subjects that travel, but also whole armies with provision" (ibid.: $\S 12,130 / 164)$. Hobbes appears to have the Spanish in mind who provisioned their armies from the Mexican mine at Mount Potosi. ${ }^{27}$ Money has the power to destabilize states, especially in the case of colonial adventurism, for once commodities have been converted into gold and silver, given "that the value of them cannot be altered by the power of one, nor of a few commonwealths, as being a common measure of commodities of all places" (ibid.), commonwealths become vulnerable to currency volatility - as the Spanish, flooding the internation-

${ }^{27}$ Hobbes in the Historia Ecclesiastica actually names Mount Potosi, the most celebrated of the Spanish colonial silver mines in the seventeenth century. See Hobbes, 2008: line 2222, 578-579. 
al market with New World silver and creating the notorious Spanish Price Rise of Hobbes's own day, learned to their cost.

If money, as at once the life-blood of the polity, and at the same time a great source of vulnerability, increases the threat of somatic invasion from without, it presents even greater opportunities for pathologies within the body politic. Hobbes creates a taxonomy of "intestine" diseases, familiar from the catalogues of distempers of popular Elizabethan literature (see Harris, 1998). He begins with the opportunities money creates for well-funded factions and demagogues, a topos also familiar from the ancient writers and novel only in the manner in which Hobbes exploits to full advantage his knowledge of his associate William Harvey's theory of the circulation of the blood. Raising first the instance of "money raising for the necessary uses of the commonwealth, especially in the approach of war", Hobbes makes his case with clear reference to the Charles I's Forced Loan of 1626-1627 and the Ship Money controversy (see Dzelzainis, 1989), in which he had supported the king, commending the royal effort to build a war chest against popular resistance:

From whence it cometh to pass that the sovereign power, which foreseeth the necessities and dangers of the commonwealth, finding the passage of money to the public treasure obstructed by the tenacity of the people, whereas it ought to extend itself to encounter and prevent such dangers in their beginnings, contracteth itself as long as it can, and when it cannot longer, struggles with the people by stratagems of law, to obtain little sums, which not sufficing, he is fain at last violently to open the way for present supply or perish; and being put often to these extremities, at last reduceth the people to their due temper, or else the commonwealth must perish. (Lev., xxix, §18, 172/217)

The memory of his own involvement in the Ship Money case seems to reactivate those passions that animated him at the time, prompting from Hobbes one of the most extravagant of a series of purple passages in his exposition of the "intestine" pathologies of the body politic, comparable only to his excoriation of the classical republicans and popular democrats as "mad dogs" of factionalism, and consistent with his somatic theory of the polity as body:

Insomuch as we may compare this distemper very aptly to an ague, wherein, the fleshy parts being congealed or by venomous matter obstructed, the veins which by their natural course empty themselves into the heart are not (as they ought to be) supplied from the arteries; whereby there succeedeth at first a cold contraction, and trembling of the limbs, and afterwards a hot and strong endeavour of the heart to force a passage for blood; and before it can do that, contenteth itself with the small refreshments of such things as cool for a time, till (if nature be strong enough) it break at last the contumacy of the parts obstructed, and dissipateth the venom into sweat, or (if nature be too weak) the patient dieth. (ibid.: 173/217-218) 
The "ague" of congestion and congestive heart failure caused by citizen obstruction over revenue-raising is complemented by the "pleurisy" caused by treasury outflow being concentrated in the hands of "one or a few private men, by monopolies or by farms of the private revenues, in the same manner as the blood in a pleurisy, getting into the membrane of the breast, breedeth there an inflammation, accompanied with a fever and painful stitches" (ibid.: §19,173/218). Hobbes sees this disease as an instance of the general pathology "aris[ing] from the opinion that every subject hath of a propriety in his lands and goods, exclusive of the sovereign's right to the use of the same" (ibid.: $\S 18,172 / 217$ ). For specification we need only turn to Behemoth, which in treating the civil war treated the challenge leading up to the regicide. There Hobbes puts into the mouth of Interlocutor B the claim: "we never shall have a lasting peace... [until] the nobility and gentry know that the liberty of a state is not an exemption from the laws of their own country, whether made by an assembly or by a monarch, but an exemption for the constraint and insolence of their neighbours" (Hobbes, Behemoth, 59), or those foreign powers that would encroach on national sovereignty weakened by internal factionalism. This is the great lesson of Hobbes's civil science, as "the science of just and unjust", a demonstrable science, accessible to those of even "the meanest capacity" (ibid.: 39; see also Springborg, 2003, 2009). It was a lesson that the Rump, who "wanted not wit, but the knowledge of the causes and grounds upon which one person has a right to govern, and the rest an obligation to obey" (Hobbes, Behemoth, 159-160), had failed to learn. In Leviathan "the rules of just and unjust sufficiently demonstrated, and from principles evident to the meanest capacity... and notwithstanding the obscurity of their author, have shined, not only in this, but also in foreign countries, to men of good education" (ibid.: 39), Hobbes boasts, grimly reminding his audience that despite the fame of his book abroad, at home "the light of that doctrine has been hitherto covered and kept under here by a cloud of adversaries, which no private man's reputation can break through, without the authority of the Universities. But out of the Universities, came all those preachers that taught the contrary." The Universities, he concludes, "have been to this nation, as the wooden horse was to the Trojans" (ibid.: 40), a swipe at the "democratical gentlemen" (ibid.: 39), products of those universities, who throw around their classical learning and "out of their reading of Tully, Seneca, and other anti-monarchics... show their discontent when they are not called to the management of the state" (ibid.: 155-156), by obstructing the Crown.

Hobbes gives no special name to the pathology caused by "the popularity of a potent subject" which is nevertheless "a dangerous disease", along the lines of that of factions and, specifically, the "democratical gentlemen", precisely "because the people (which should receive their motion from the authority of the sovereign), by the flattery and by the reputation of an ambitious man, are drawn away from their 
obedience to the laws" (Lev., xxix, §20, 174/218). He takes as his example "Julius Caesar, who was set up by the people against the Senate, having won to himself the affections of his army, [but] made himself master, both of Senate and people" (ibid.). In De Cive Hobbes had taken rather Sallust's Cataline to illustrate the same point. "No one was made more for sedition than Cataline; he is portrayed in Sallust as having adequate eloquence but little wisdom"; and Hobbes pays homage to the Roman historian, for: "Sallust separates wisdom from eloquence, attributing the latter to him [Cataline] as essential to a born rabble-rouser, denying him wisdom because wisdom dictates peace" (Hobbes, On the Citizen, 121). Hobbes the philosopher of peace was himself not lacking in eloquence in concluding of Caesar's case that "this proceeding of popular and ambitious men is plain rebellion, and may be resembled to the effects of witchcraft" (Lev., xxix, §20, 174/218).

The "ague" and "pleurisy" caused by individuals or factions, in syphoning off resources due to the sovereign, has its analogue in the pathology of "the immoderate greatness of a town, when it is able to furnish out of its own circuit, the number and expense of a great army" - and here he probably refers to the Scots who defeated the King's army three times, in 1640, in 1646 and in 1648, finally to be defeated by Cromwell's London-based New Model Army in turn. The city of "immoderate greatness", together with "the great number of corporations (incorporated towns), which are as it were many lesser commonwealths in the bowels of the greater, [are] like worms in the entrails of a natural man" (ibid.). Hobbes this time puts together the power of factions with that of the cities which are their hosts, returning to the subject of the "democratical gentlemen", as "pretenders to political prudence", enjoying "the liberty of disputing against absolute power... which though bred for the most part in the lees (dregs) of the people, yet animated by false doctrines, are perpetually meddling with the fundamental laws, to be the molestation of the commonwealth, like the little worms, which physicians call ascarides" (ibid.), parasites specific to the human intestinal tract that are quite capable of killing the host. When the host is dead, due to war or intestinal disease, it is all over and the sovereign as the soul of the body, consistent with Hobbes's mortalism, cannot be revived:

Lastly, when in a war (foreign or intestine) the enemies get a final victory, so as (the forces of the commonwealth keeping the field no longer), there is no farther protection of subjects in their loyalty, then is the commonwealth DISSOLVED, and every man at liberty to protect himself by such courses as his own discretion shall suggest unto him. For the sovereign is the public soul, giving life and motion to the commonwealth, which expiring, the members are governed by it no more than the carcass of a man by his departed (though immortal) soul. ${ }^{28}$

${ }^{28}$ Lev., xxix, §23, 175/218-219. We know that Hobbes denies the soul is immortal, and clearly for this reason one's dead carcass can no longer be governed by it, present or absent. 
What Hobbes gives with one hand he takes with another. Seeming momentarily to endorse a notion of the soul, he nevertheless immediately denies the possibility of its outliving the body. And this is the "mortalism" that earned him the epithets "heretic" and "blasphemer". ${ }^{29}$ In fact he is ruthlessly consistent in the application of his materialism and the principle that "every part of the universe is body, and that which is not body is no part of the universe". ${ }^{30}$ Political bodies he treats as natural bodies, united in their representatives, which are their heads. But the international system as a default category has no extension or mass, and therefore is not a body. Precisely because it is not a body as such, there is no organic analogy for it, it is a vacuum, or medium which is host to political bodies, ever in motion and never at rest, like billiard balls in space. From this later political theorists have extrapolated a condition of anarchy, on the analogue of the state of nature. But Hobbes has little to say about the international system of states, born only in 1648 with the Treaty of Westphalia, beyond the fact that it has no sovereign, and for this reason urging caution on national bodies not to overextend themselves or offer provocations to wars that, in the absence of world government, cannot easily be concluded. Hobbes's theory of territorial empire as a threat to the longevity of the commonwealth is along the same lines of lack of balance leading to disequilibrium that we find in the classical authors. If "potent subjects" and "the immoderate greatness of a town" constitute threats, so does the grandiose enlargement of dominion, arguments reminiscent of Aristotle and his observation that among the causes of revolution are "ambition, fear, superiority, contempt, and disproportionate growth" which he likens to the big foot whose disproportion spoils the proportion of the whole. ${ }^{31}$

So with plantations and colonies, fruit of "the insatiable appetite, or Bulimia, of enlarging dominion", which expose us to "the incurable wounds thereby many times received from the enemy, and the wens (warts), of ununited conquests", listed by Hobbes among the liabilities of vain-glory, "which are many times a burden, and with less danger lost than kept"; as belonging with "the lethargy of ease, and consumption of riot and vain expense", all better expunged than retained (ibid.: §22,

29 Samuel Mintz in his study of Hobbes's reception, The Hunting of Leviathan (1962: 45), summarizes the reasons critics gave for calling Hobbes an atheist as follows: "that the universe is body, that God is part of the world and therefore body, ... that the members of the Trinity are Moses, Jesus, and the Apostles, ... that witchcraft is a myth and heaven a delusion", and that the soul is mortal, dying with the body.

${ }^{30}$ Lev., xlvi, $§ 15,371 / 459$. A rule that also forced him to insist on a Corporeal God, see Springborg, 2012.

31 Aristotle, Politics, Bk V, ch. iii, 1302b: "Political revolutions also spring from a disproportionate increase in any part of the state. For as a body is made up of many members, and every member ought to grow in proportion, that symmetry may be preserved; but loses its nature if the foot be four cubits long and the rest of the body two spans." 
175/218). Hobbes, the philosopher of peace, is also a minimalist along classical lines, eschewing luxury, vain-glory and its customary excesses, vain-glorious war and imperial grandstanding. In this respect he is at a far remove from the Elizabethan adventurers of the generation immediately previous to his, Drake, Ralegh and his mentor Francis Bacon, enthusiasts for the plantation of colonies, whatever he may have thought of the law of empire being promulgated by his peers, Hugo Grotius and John Selden; just as he was also at a far remove from John Locke, as yet unborn, the Secretary for Plantations. His theory is remarkably backward-looking in terms of its emphasis on the health of the body politic, homeostasis and the politics of balance, forbidding "vain-glorious wars", overly-powerful subjects, towns of "immoderate greatness", and foreign adventurism leading to grandiose enlargements of dominion, empire and war.

\section{Acknowledgment}

This paper was presented in an earlier form as "Hobbes on Empire, War and Peace" to the International Peace Studies Conference, University of Sydney, Sydney Australia, July 6-10, 2010. In its present form it was presented to the workshop on Thomas Hobbes and Peace at the University of Edinburgh, June 8-9, 2017; the University of Naples "Parthenope", at the invitation of Professor Olivier Butzbach, October 17, 2017; and the Summer School in Modern Political Theory, "Bourgeois and Citoyen, Political Aspects of Economy", Grožnjan, Croatia, July 16-21, 2018. I especially wish to thank Luka Ribarević from the Zagreb Political Science Department, an organizer of the Grožnjan Summer School, for his encouragement and assistance.

\section{REFERENCES}

Adamson, John. 1999. The Tudor and Stuart Courts 1509-1714, in: Adamson, J. (ed.): The Princely Courts of Europe: Ritual, Politics and Culture under the Ancien Régime 1500-1750. Seven Dials, Cassell \& Co. London: 95-117.

Aristotle. Politics, http://files.libertyfund.org/files/579/0033-01_Bk_SM.pdf.

Bobbitt, Philip. 2002. The Shield of Achilles. War, Peace and the Course of History. Alfred A. Knopf. New York.

Bredekamp, Horst. 1999. From Walter Benjamin to Carl Schmitt, via Thomas Hobbes. Critical Inquiry, (25), 2: 247-266.

Bredekamp, Horst. 2006. Thomas Hobbes Visuelle Strategien. Akademie Verlag. Berlin. 
Cole, Thomas. 1967. Democritus and the Sources of Greek Anthropology. American Philological Association Monographs, no 25. Western Reserve University. Ohio.

Coleman, Janet. 1985. Dominium in Thirteenth and Fourteenth-Century Political Thought and its Seventeenth-Century Heirs: John of Paris and Locke. Political Studies, (33), 1: 73-100.

Cuddy, Neil. 1987. The Revival of the Entourage: the Bedchamber of James I, 16031625, in: Starkey, D. (ed.): The English Court: from the Wars of the Roses to the Civil War. Longman. London.

Deckard, Michael Funk. 2010. Hobbes on Peace: Anthropology and the Politics of the Sovereign. Unpublished Paper presented to the International Peace Studies Conference, University of Sydney, Sydney Australia, July 6-10.

Deckard, Michael Funk. 2011. Review - Hobbes: Prince of Peace. Metapsychology Online Reviews, (15), 6.

Dzelzainis, Martin. 1989. Edward Hyde and Thomas Hobbes's Elements of Law, Natural and Politic. The Historical Journal, (32), 2: 303-317.

Gert, Bernard, 2010. Hobbes: Prince of Peace. Polity. Cambridge.

Haggenmacher, Peter. 1983. Grotius et la doctrine de la guerre juste. PUF. Paris.

Harris, Jonathan Gil. 1998. Foreign Bodies and the Body Politic: Discourses of Social Pathology in Early Modern England. Cambridge University Press. Cambridge.

Herz, John H. 1951. Political Realism and Political Idealism. University of Chicago Press. Chicago.

Hobbes, Thomas. 1969. The Elements of the Law Natural and Politic. Ed. Ferdinand Tönnies, $2^{\text {nd }}$ edn, ed. M. M. Goldsmith. Barnes \& Noble. London.

Hobbes, Thomas. 1971. A Dialogue between a Philosopher \& a Student of the Common Laws of England. Ed. J. Cropsey. University of Chicago Press. Chicago.

Hobbes, Thomas. 1990. Behemoth, or The Long Parliament. Ed. Ferdinand Tönnies, London, 1889, facsimile ed., ed. Stephen Holmes. University of Chicago Press. Chicago.

Hobbes, Thomas. 1994. Leviathan [1651], with selected variants from the Latin edition of 1668, ed. Edwin Curley. Hackett. Indianapolis. Citations, henceforth given intext, reference chapter (small Roman numerals), section (§), and pagination of the Head edition/and of the Curley edition.

Hobbes, Thomas. 1998. On the Citizen (De Cive, 1641). Eds. Richard Tuck and Michael Silverthorpe. Cambridge University Press. Cambridge.

Hobbes, Thomas. 2008. Historia Ecclesiastica. Critical edition, including text, translation, introduction, commentary and notes by Patricia Springborg, Patricia Stablein and Paul Wilson. Honoré Champion. Paris.

Jelenko, Gustav. 1936. Die Komposition der Kulturgeschichte des Lucretius. Wiener Studien, 54: 59-69. 
Jervis, Robert. 1976. Perception and Misperception in International Politics. Princeton University Press. Princeton, N. J.

Jervis, Robert. 1978. Cooperation Under the Security Dilemma. World Politics, (30), 2: 167-214.

MacPherson, C. B. 1962. The Political Theory of Possessive Individualism: Hobbes to Locke. Oxford University Press. Oxford.

Malcolm, Noel. 1981. Hobbes, Sandys and the Virginia Company. The Historical Journal, (24), 2: 297-321.

Malcolm, Noel. 2002. Aspects of Hobbes. Clarendon Press. Oxford.

Mearsheimer, John. 2004. The Tragedy of Great Power Politics. W. W. Norton \& Company. New York.

Milton, John. 1645. Tetrachordon: Expositions upon the four chief Places in Scripture which treat of Marriage or Nullities in Marriage. London.

Mintz, Samuel. 1962. The Hunting of Leviathan. Cambridge University Press. Cambridge.

Morgenthau, Hans. 1992. Politics Among Nations, Brief Edition: The Struggle for Power and Peace. McGraw-Hill Higher Education. Boston.

Nye, Joseph. 2004. Soft Power: The Means to Success in World Politics. Washington. Public Affairs.

Plutarch. 1965. The Makers of Rome. Penguin. London.

Roe, Paul. 1999. The Intrastate Security Dilemma: Ethnic Conflict as a 'Tragedy'? Journal of Peace Research, (36), 2: 183-202.

Schmitt, Carl. 1938/1995. Der Leviathan in der Staatslehre des Thomas Hobbes. Sinn und Fehlschlag eines politischen Symbols. Klett-Cotta. Stuttgart.

Schmitt, Carl. 1996. The Leviathan in the State Theory of Thomas Hobbes. Translated by George Schwab. Greenwood Press. Westport, Connecticut.

Sharpe, Kevin. 1983. Faction at the Early Stuart Court. History Today, (33), 10: 39-46.

Sharpe, Kevin. 1987. The Image of Virtue: The Court and Household of Charles I, 16251642, in: Starkey, D. (ed.): The English Court: from the Wars of the Roses to the Civil War. Longman. London: 226-260.

Shephard, Robert. 1992. Court Factions in Early Modern England. Journal of Modern History, (64), 4: 721-745.

Spoerri, Walter von. 1957. Über die Quellen des Kulturentstehung des Tzetzes. Museum Helveticum, (14): 183-188.

Spoerri, Walter von. 1959. Späthellenistische Berichte über Welt, Kultur und Götter. Friedrich Rienhardt. Basel.

Springborg, Patricia. 1981. The Problem of Human Needs and the Critique of Civilization. Allen \& Unwin. London. 
Springborg, Patricia. 2003, 2009. Behemoth and Hobbes's 'Science of Just and Unjust'. Filozofski vestnik, special issue on Hobbes's Behemoth, ed. Tomaz Mastnak, (24), 2 (2003): 267-89. Reprinted in: Mastnak, Tomaz (ed.). 2009. Hobbes's Behemoth: Religion and Democracy. Academic Imprint. Exeter, UK: 148-169.

Springborg, Patricia. 2010a. Hobbes's Fool the Stultus, Grotius, and the Epicurean Tradition. Hobbes Studies, (23), 1: 29-53.

Springborg, Patricia. 2010b. Hobbes and Schmitt on the Name and Nature of Leviathan Revisited. Critical Review of International Social and Political Philosophy, (13), 2-3: 297-315.

Springborg, Patricia. 2012. Hobbes's Challenge to Descartes, Bramhall and Boyle: A Corporeal God. British Journal for the History of Philosophy, (20), 5: 903-934.

Springborg, Patricia. 2015. Hobbes, Donne, and the Virginia Company: Terra Nullius and 'the Bulimia of Dominium'. History of Political Thought, 36, 1: 113-164.

Thivet, Delphine. 2008. Thomas Hobbes: a Philosopher of War or Peace? British Journal for the History of Philosophy, (16), 4: 701-721.

Thucydides. 1989. Eight Bookes of the Peloponnesian Warre Written by Thvcydides the Sonne of Olorvs Interpreted with Faith and Diligence Immediately out of the Greeke [London, 1629]. Translation by Thomas Hobbes, ed. David Grene. Chicago University Press. Chicago.

Tralau, Johan (ed.). 2011. Thomas Hobbes and Carl Schmitt. The Politics of Order and Myth. Routledge. London.

Uxkull-Gyllenband, Woldemar Graf. 1924. Griechische Kultur-Entstehungslehren. Leonhard Simion. Berlin.

Waltz, Kenneth. 2000. Structural Realism after the Cold War. International Security, (25), 1: 5-41.

Wendt, Alexander. 1992. Anarchy is What States Make of it: The Social Construction of Power Politics. International Organization, (46), 2: 391-426.

Wendt, Alexander, 1999. The Social Theory of International Politics. Cambridge University Press. Cambridge.

Wootton, David. 1999. Francis Bacon: Your Flexible Friend, in: Elliott, J. H. and Brockliss, L. W. B. (eds): The World of the Favourite. Yale University Press. New Haven: 184-204.

Mailing Address: Patricia Springborg, Guest Professor and Fellow, Centre for British Studies, Humboldt University, Mohrenstr. 60, 10117 Berlin Mitte. E-mail: springbp@hu-berlin.de 